\title{
Phenolic profiling and in vitro bioactivities of three medicinal Bryophyllum plants
}

\author{
Pascual García-Pérez ${ }^{\text {a,b }}$, Manuel Ayuso ${ }^{\text {a,c }}$, Eva Lozano-Milo ${ }^{\text {a,b }}$, Carla Pereira ${ }^{\text {c, }}$ \\ Maria Inês Dias $^{c}$, Marija Ivanov ${ }^{\mathrm{d}}$, Ricardo C. Calhelha ${ }^{\mathrm{c}}$, Marina Soković ${ }^{\mathrm{d}}$, Isabel C.F. \\ R. Ferreira ${ }^{c}$, Lillian Barros ${ }^{c, *}$, Pedro P. Gallego ${ }^{a, b, *}$ \\ a Applied Plant and Soil Biology, Plant Biology and Soil Science Department, Biology Faculty, University of Vigo, Vigo, Spain \\ ${ }^{\mathrm{b}}$ CITACA - Agri-Food Research and Transfer Cluster, University of Vigo, Ourense, Spain \\ c Centro de Investigação de Montanha (CIMO), Instituto Politécnico de Bragança, Campus de Santa Apolónia, 5300-253 Bragança, Portugal \\ ${ }^{\mathrm{d}}$ Institute for Biological Research "Siniša Stanković"- National Institute of Republic of Serbia, University of Belgrade, Bulevar despota Stefana 142, Belgrade, Serbia
}

\section{A R T I C L E I N F O}

\section{Keywords:}

Kalanchoe plant in vitro culture

flavonoids

anthocyanins

bioactive properties

phytochemical potential

\begin{abstract}
A B S T R A C T
Bryophyllum constitutes a subgenus within the genus Kalanchoe that contains several plant species used in traditional medicine worldwide for the treatment of several diseases. However, little is known about the phytoconstituents of Bryophyllum spp. and previous reports have pointed at their low in Planta concentrations of bioactive compounds. In this work, we take advantage of plant in vitro culture for the study of the phenolic compounds found in the aerial parts of Bryophyllum spp. and their associated bioactivities. Our results show that the induction of nutritional stress leads to an improved accumulation of phenolic compounds, mainly flavonols and anthocyanins, represented by myricetin and malvidin glycosides, respectively. This effect is mainly found for B. $\times$ houghtonii, whose hydroethanolic extracts promoted the highest antioxidant, cytotoxic and antiinflammatory activities. In the case of cytotoxic activity, Bryophyllum extracts showed an enhanced activity against the MCF-7 human breast carcinoma cell line. Meanwhile, extracts from $B$. daigremontianum promoted a wide range of effectiveness against different bacterial and fungal strains. This study is committed to shed light about the phytochemical potential associated to this unexplored subgenus, with the aim of considering Bryophyllum spp. as a valuable source of bioactive compounds for their exploitation in food, cosmetic and pharmaceutical industries.
\end{abstract}

\section{INTRODUCTION}

The subgenus Bryophyllum (genus Kalanchoe, Crassulaceae) contains more than 25 species widely used for ornamental and medicinal purposes (Descoings, 2006). The medicinal properties attributed to Bryophyllum spp. have been reported by their use as part of plant-derived formulations in the traditional medicine across Africa, Asia and South America (Fürer et al., 2016; García-Pérez et al., 2019). Hence, Bryophyllum formulations have been used in the traditional medicine for the treatment of several ailments including infections, diabetes, rheumatism and inflammatory and neoplastic diseases across Africa, Asia and South America (Kolodziejczyk-Czepas and Stochmal, 2017; Quazi Majaz et al., 2011). Such medicinal properties are a consequence of the vast number of secondary metabolites found in several Bryophyllum species, that can be classified into different families, such as phenolic compounds, bufadienolides and isoprenoids, among others (Milad, 2014).

Nevertheless, the phytochemical studies of these species have focused on the identification and quantification of bufadienolides and their associated cytotoxic bioactivity (Fürer et al., 2016; Kolodziejczyk-Czepas and Stochmal, 2017; Stefanowicz-Hajduk et al., 2020a). In contrast, the analysis of phenolic compounds is scarce and only limited information is available about this family of phytoconstituents on Bryophyllum spp. (Bogucka-Kocka et al., 2016), which have been widely reported as antioxidant, anti-inflammatory, anti-microbial and cytotoxic agents (Oroian and Escriche, 2015).

Moreover, phytochemical studies conducted on Bryophyllum spp. have been performed using raw plant materials from conventional breeding. Consequently, an excessive amount of plant biomass was needed, as very low yields were achieved (de Paiva et al., 2008d; Mahata et al., 2012). As a solution, the establishment of Bryophyllum plant in

\footnotetext{
* Corresponding author at: Applied Plant and Soil Biology, Plant Biology and Soil Science Department, Biology Faculty, University of Vigo, Vigo, Spain.

E-mail addresses: lillian@ipb.pt (L. Barros), pgallego@uvigo.es (P.P. Gallego).
} 
vitro culture emerges as a powerful tool to consider their potential as a valuable source of bioactive compounds (García-Pérez et al., 2019a, 2020a, 2020b, 2020c). Plant tissue culture technology offers some advantages to accomplish this goal, such as the independence of geoclimatic conditions, the absence of potential pollutants (avoiding the use of pesticides and other chemicals), and the capability to get a stable production of true-to-type plant-derived products (Dias et al., 2016). Additionally, plant tissue culture enables the modulation of secondary metabolite biosynthesis, mediated by the induction of plant stress throughout a phenomenon known as elicitation (Moon et al., 2020). Elicitation has been implemented as an effective strategy for enhancing secondary metabolite activity, enabling their production at industrial level, as reported for a wide range of plant species (Narayani and Srivastava, 2017). Furthermore, the success of Bryophyllum in vitro culture is supported by the exceptional asexual reproduction developed along the leaf margins of mature plants, which involves the generation fully-developed epiphyllous plantlets (Garcês and Sinha, 2009; Garcês et al., 2014), as already demonstrated (García-Pérez et al., 2020d).

In the present work, the identification and quantification of phenolic compounds from three in vitro-cultured Bryophyllum species was performed, providing valuable information about the heterogeneity of these compounds. In addition, the induction of nutritional stress by reducing the concentration of macronutrients on the culture media as a potential strategy to enhance the production of phenolic compounds (García-Pérez et al., 2020b), was evaluated. Finally, different biological activities, including antioxidant, cytotoxic, anti-inflammatory and antimicrobial were assessed, in order to determine the health-enhancing properties associated to Bryophyllum cultured in vitro. The knowledge provided by this work will aid considering the unexploited potential of these medicinal plants from the Bryophyllum subgenus as valuable sources of bioactive compounds for industrial purposes.

\section{MATERIALS AND METHODS}

\subsection{Plant material and culture conditions}

Three different species belonging to Bryophyllum subgenus were used in this work, namely: Bryophyllum daigremontianum Raym. - Hamet et Perr. (syn. Kalanchoe daigremontiana), Bryophyllum $\times$ houghtonii D.B. Ward (B. daigremontianum $\times$ tubiflorum, syn. Kalanchoe daigremontiana $\times$ tubiflora) and Bryophyllum tubiflorum Harv. (syn. Kalanchoe tubiflora). One-year-old plants were harvested in a local greenhouse (Vigo, Spain) and epiphyllous plantlets were detached from mother plants. Then, plantlets were disinfected and subjected to in vitro culture conditions as previously reported (García-Pérez et al., 2019a). Briefly, after disinfection, plantlets were transferred in pairs to glass culture vessels containing $25 \mathrm{~mL}$ of previously autoclaved full-strength MS medium (Murashige and Skoog, 1962) or half-strength macronutrient MS medium (1/2MS; García-Pérez et al., 2020b). The 1/2MS formulation was already applied to Bryophyllum in vitro culture for the induction of nutritional stress, leading to the production of phenolic compounds (García-Pérez et al., 2020b). Cultures were then randomly placed in growth chambers under a photoperiod of $16 \mathrm{~h}$ light and $8 \mathrm{~h}$ dark at $25 \pm$ $1{ }^{\circ} \mathrm{C}$ for 12 weeks. Plants were subcultured every 12 weeks by transferring newly-formed plantlets to fresh culture medium, as previously established (García-Pérez et al., 2020b). After each subculture, aerial parts from 12-week-old in vitro-grown plants were excised and immediately frozen at $-20{ }^{\circ} \mathrm{C}$ until use. Aerial parts from three consecutive subcultures were merged prior sample extraction, as described in the next section.

\subsection{Sample extraction}

Once frozen, samples were lyophilized, powder homogenized and subjected to solid-liquid extraction, using $1.0 \mathrm{~g}$ of lyophilized materials and $30 \mathrm{~mL}$ of $80 \%(\mathrm{v} / \mathrm{v}) \mathrm{EtOH}$ for $1 \mathrm{~h}$ at $150 \mathrm{rpm}$ at room temperature.
Samples were extracted twice and supernatants were combined to get the raw extract. Extracts were then filtered throughout Whatmann paper no. 4 and concentrated under reduced pressure in a rotary evaporator. The aqueous phase was removed by lyophilization and the solid dry extract was resuspended with $20 \%(\mathrm{v} / \mathrm{v}) \mathrm{EtOH}$ at a final concentration of $5 \mathrm{mg} \mathrm{mL}{ }^{-1}$. Hydroethanolic extracts were filtered using $0.22 \mu \mathrm{m}$ disposable LC filter disks, prior to their chromatographic analysis.

For the analysis of anthocyanins, the sample extraction procedure was performed under the same conditions but using acidified $80 \%(\mathrm{v} / \mathrm{v})$ EtOH with $1 \%(\mathrm{v} / \mathrm{v})$ trifluoroacetic acid as solvent.

\subsection{Analysis of phenolic compounds}

The analysis of phenolic compounds was performed by HPLC-DADESI/MS ${ }^{\mathrm{n}}$ (Dionex Ultimate 3000 UPLC, Thermo Scientific, San Jose, CA, USA), as previously reported by Bessada et al. (2016) for the non-anthocyanin phenolic compounds and by Gonçalves et al. (2017) for the anthocyanin compounds. The detection of phenolic compounds was achieved using diode-array detector programmed with the preference wavelengths at 280, 330 and $370 \mathrm{~nm}$ for non-anthocyanin phenolic compounds, and $520 \mathrm{~nm}$ for anthocyanin compounds, also coupled to a Linear Ion Trap LTQ XL mass spectrometer (Thermo Finnigan, San Jose, CA, USA), working in negative (identification of non-anthocyanin phenolic compounds) and positive (identification of anthocyanin compounds) mode and was equipped with an ESI source.

Identification of phenolic compounds was achieved through their comparison to commercial standards, when available, in terms of their retention times and UV-Vis spectra. When standards were not available, tentative identification was offered, based on additional information from the literature. Quantitative analysis was developed using calibration curves obtained from the UV-Vis signal of available phenolic standards: naringenin $\left(\mathrm{y}=18433 \mathrm{x}+78903 ; \mathrm{R}^{2}=0.9998\right)$, apigenin-6-Cglucoside $\left(\mathrm{y}=107025 \mathrm{x}+61531 ; \mathrm{R}^{2}=0.9989\right)$, quercetin-3-O-rutinoside $\left(\mathrm{y}=13343 \mathrm{x}+76751 ; \mathrm{R}^{2}=0.9998\right)$, myricetin $(\mathrm{y}=23287 \mathrm{x}-$ $\left.581708 ; \mathrm{R}^{2}=0.9988\right)$, quercetin-3-O-glucoside $(\mathrm{y}=34843 \mathrm{x}-160173$; $\left.\mathrm{R}^{2}=0.9998\right)$ and peonidin-3-O-glucoside $\left(\mathrm{y}=151438 \mathrm{x}-\left(310^{6}\right) ; \mathrm{R}^{2}=\right.$ 0.9977). Results were expressed as $\mathrm{mg} \mathrm{g}^{-1}$ of dry extract.

\subsection{Evaluation of in vitro biological activities}

\subsubsection{Antioxidant activity}

In order to determine the antioxidant activity associated to Bryophyllum extracts, two different in vitro assays were conducted, including the determination of extracts capacity on the inhibition of thiobarbituric acid reactive substances (TBARS) and oxidative hemolysis (OxHLIA), based on previous works (Lockowandt et al., 2019). In both cases, oxidizable subtracts were used: porcine brain cells for TBARS assay and sheep erythrocytes for OxHLIA assay ( $\Delta \mathrm{t}=60 \mathrm{~min}$ ). Trolox was selected as positive control for both assays and results were expressed as $\mathrm{IC}_{50}$ values, in $\mu \mathrm{g} \mathrm{mL} \mathrm{L}^{-1}$.

\subsubsection{Cytotoxic and hepatotoxic activity}

Plant extracts at the concentration of $50-400 \mu \mathrm{g} \mathrm{mL}^{-1}$ (in water) were used for the determination of cytotoxic activity by the sulforhodamine $\mathrm{B}$ method (Guimarães et al., 2013) against different human tumor cell lines: NCI-H460 (non-small cell lung carcinoma), MCF-7 (breast adenocarcinoma), HeLa (cervical carcinoma) and HepG2 (hepatocellular carcinoma). The non-tumor PLP2 cell line (porcine liver primary cells) was used for the determination of hepatotoxicity. Elipticine was selected as the positive control, and the results were expressed as $\mathrm{GI}_{50}$ values, in $\mu \mathrm{g} \mathrm{mL} \mathrm{m}^{-1}$.

\subsubsection{Anti-inflammatory activity}

Plant extracts at the concentration of $0.125-0.4 \mathrm{mg} \mathrm{mL}^{-1}$ (in water) were tested for the determination of anti-inflammatory activity. Briefly, the stimulation of murine macrophages RAW 264.7 cell line (provided 
by European Collection of Animal Cell Culture, ECACC, Salisbury, UK) by lipopolysaccharide (LPS), was measured by means of nitric oxide (NO) production by using the Griess Reagent System kit (Promega, WI, USA), as previously described (Souilem et al., 2017). Dexamethasone was used as positive control and the results were expressed as $\mathrm{IC}_{50}$ values, in $\mu \mathrm{g} \mathrm{mL}^{-1}$.

\subsubsection{Antimicrobial activity}

Plant extracts at the concentration of $0.1-20 \mathrm{mg} \mathrm{mL}^{-1}$ (in $30 \%$ ethanol) were tested for antibacterial and antifungal assays through the microdilution method (Heleno et al., 2013). All microorganisms were provided by the Institute for Biological Research "Sinisa Stanković" National institute of Republic of Serbia, University of Belgrade, Serbia. For antibacterial analysis the next three Gram-positive strains: Bacillus cereus (food isolate), Listeria monocytogenes (NCTC7973) and Staphylococcus aureus (ATCC 6538); and the next Gram-negative strains: Escherichia coli (ATCC 25922), Enterobacter cloacae (ATCC 35030) and Salmonella Typhimurium (ATCC13311) were used. For antifungal activity, the selected Aspergillus strains: A. fumigatus (ATCC 1022), A. ochraceus (ATCC 12066) and A. niger (ATCC 6275); and Penicillium strains: P. ochrochloron (ATCC 9112), P. funiculosum (ATCC 36839) and $P$. verrucosum var. cyclopium (food isolate) were used. Streptomycin and ampicillin were used as a positive control for antibacterial assays, whereas ketoconazole and bifonazole were selected as positive control for the antifungal assays, while $30 \%$ ethanol was used as a negative control. The results were presented as minimum inhibitory concentration (MIC, required for microbial growth inhibition), bactericidal (MBC) and fungicidal concentrations (MFC), expressed in $\mathrm{mg} \mathrm{mL}^{-1}$.

Table 1

Identification and quantification of phenolic compounds by HPLC-DAD-ESI/MS ${ }^{\mathrm{n}}$ of hydroethanolic extracts from Bryophyllum spp. cultured in vitro.

\begin{tabular}{|c|c|c|c|c|c|c|c|c|c|c|c|}
\hline \multirow{3}{*}{ Peak } & \multirow{3}{*}{$\begin{array}{l}\text { Rt } \\
(\min )\end{array}$} & \multirow{3}{*}{$\begin{array}{l}\lambda_{\max } \\
(\mathrm{nm})\end{array}$} & \multirow{3}{*}{$\begin{array}{l}{[\mathrm{M}-\mathrm{H}]-/} \\
{[\mathrm{M}]^{+}} \\
(m / z)\end{array}$} & \multirow{3}{*}{$\begin{array}{l}\mathrm{MS}^{2} \\
(m / z)\end{array}$} & \multirow{3}{*}{ Tentative identification } & \multicolumn{6}{|c|}{ Content ( $\mathrm{mg} \mathrm{g}^{-1}$ extract) } \\
\hline & & & & & & \multicolumn{2}{|c|}{ B. daigremontianum } & \multicolumn{2}{|c|}{ B. $\times$ houghtonii } & \multicolumn{2}{|l|}{ B. tubiflorum } \\
\hline & & & & & & MS & 1/2MS & MS & $1 / 2 \mathrm{MS}$ & MS & 1/2MS \\
\hline \multicolumn{12}{|c|}{ Non-anthocyanins phenolic compounds } \\
\hline 1 & 8.76 & 298 & 449 & $287(100)$ & Eriodictyol-O-hexoside $^{1}$ & $\operatorname{tr}$ & $\begin{array}{l}0.53 \pm \\
0.02^{\mathrm{A}}\end{array}$ & $\operatorname{tr}$ & $\operatorname{tr}$ & nd & $\begin{array}{l}0.16 \pm \\
0.01^{\mathrm{B}}\end{array}$ \\
\hline 2 & 9.62 & 327 & 593 & $\begin{array}{l}473(100), 383 \\
(11), 353(19)\end{array}$ & Apigenin- $C$-dihexoside ${ }^{2}$ & nd & nd & $\begin{array}{l}0.26 \pm \\
0.01^{\mathrm{bB}}\end{array}$ & $\begin{array}{l}0.40 \pm \\
0.01^{\mathrm{aB}}\end{array}$ & $\begin{array}{l}0.798 \pm \\
0.002^{\mathrm{bA}}\end{array}$ & $\begin{array}{l}0.93 \pm \\
0.04^{\mathrm{aA}}\end{array}$ \\
\hline 3 & 14.06 & $\begin{array}{l}265 / \\
\operatorname{sh} 309\end{array}$ & 725 & $\begin{array}{l}563(40), 285 \\
(100)\end{array}$ & $\begin{array}{l}\text { Kaempferol-O-deoxyhexoside- } \\
\text { pentoside- } O \text {-hexoside }{ }^{3}\end{array}$ & $\operatorname{tr}$ & $\operatorname{tr}$ & $\operatorname{tr}$ & $\operatorname{tr}$ & nd & nd \\
\hline 4 & 15.12 & 352 & 479 & $317(100)$ & Myricetin-3-O-glucoside $^{4}$ & $\begin{array}{l}5.20 \pm \\
0.01^{\mathrm{bA}}\end{array}$ & $\begin{array}{l}5.28 \pm \\
0.02^{\mathrm{aA}}\end{array}$ & $\begin{array}{l}5.09 \pm \\
0.01^{\mathrm{aB}}\end{array}$ & $\begin{array}{l}5.11 \pm \\
0^{\mathrm{aB}}\end{array}$ & $\begin{array}{l}5.063 \pm \\
0.002^{\mathrm{aB}}\end{array}$ & $\begin{array}{l}5.07 \pm \\
0.01^{\mathrm{aC}}\end{array}$ \\
\hline 5 & 17.41 & 345 & 463 & $317(100)$ & Myricetin-O-deoxyhexoside ${ }^{4}$ & $\begin{array}{l}5.11 \pm \\
0.00^{\mathrm{bA}}\end{array}$ & $\begin{array}{l}5.22 \pm \\
0.01^{\mathrm{aA}}\end{array}$ & $\begin{array}{l}5.042 \pm \\
0.003^{\mathrm{bC}}\end{array}$ & $\begin{array}{l}5.08 \pm \\
0.01^{\mathrm{aB}}\end{array}$ & $\begin{array}{l}5.08 \pm \\
0.01^{\mathrm{aB}}\end{array}$ & $\begin{array}{l}5.06 \pm \\
0.01^{\mathrm{aC}}\end{array}$ \\
\hline 6 & 18.07 & 350 & 595 & $317(100)$ & $\begin{array}{l}\text { Myricetin-O-pentosyl } \\
\text { deoxyhexoside }^{4}\end{array}$ & $\begin{array}{l}5.29 \pm \\
0.01^{\mathrm{bA}}\end{array}$ & $\begin{array}{l}5.62 \pm \\
0.02^{\mathrm{aA}}\end{array}$ & $\begin{array}{l}5.06 \pm \\
0.01^{\mathrm{bB}}\end{array}$ & $\begin{array}{l}5.12 \pm \\
0.01^{\mathrm{aB}}\end{array}$ & $\begin{array}{l}5.064 \pm \\
0.002^{\mathrm{aB}}\end{array}$ & $\begin{array}{l}5.07 \pm \\
0.02^{\mathrm{aB}}\end{array}$ \\
\hline 7 & 18.60 & 348 & 595 & $317(100)$ & $\begin{array}{l}\text { Myricetin- } O \text {-pentosyl } \\
\text { deoxyhexoside }^{4}\end{array}$ & $\begin{array}{l}5.18 \pm \\
0.01^{\mathrm{bA}}\end{array}$ & $\begin{array}{l}5.28 \pm \\
0.02^{\mathrm{aA}}\end{array}$ & $\begin{array}{l}5.04 \pm \\
0.01^{\mathrm{aB}}\end{array}$ & $\begin{array}{l}5.07 \pm \\
0.01^{\mathrm{aB}}\end{array}$ & nd & nd \\
\hline 8 & 19.08 & 345 & 595 & $317(100)$ & $\begin{array}{l}\text { Myricetin-O-pentosyl } \\
\text { deoxyhexoside }^{4}\end{array}$ & $\begin{array}{l}5.113 \pm \\
0.003^{\mathrm{bA}}\end{array}$ & $\begin{array}{l}5.19 \pm \\
0.01^{\mathrm{aA}}\end{array}$ & $\begin{array}{l}5.030 \pm \\
0.003^{\mathrm{aB}}\end{array}$ & $\begin{array}{l}5.05 \pm \\
0.01^{\mathrm{aB}}\end{array}$ & nd & nd \\
\hline 9 & 20.17 & 334 & 549 & $\begin{array}{l}505(25), 463 \\
(20), 301 \\
(100)\end{array}$ & $\begin{array}{l}\text { Quercetin-O- } \\
\text { malonylhexoside }\end{array}$ & $\operatorname{tr}$ & $\operatorname{tr}$ & nd & nd & nd & nd \\
\hline 10 & 20.17 & 334 & 463 & $301(100)$ & Quercetin-O-glucoside ${ }^{5}$ & nd & $\begin{array}{l}1.008 \pm \\
0.004^{\mathrm{B}}\end{array}$ & $\begin{array}{l}1.32 \pm \\
0.01^{\mathrm{aA}}\end{array}$ & $\begin{array}{l}1.24 \pm \\
0^{\mathrm{bA}}\end{array}$ & $1.08 \pm 0^{\mathrm{aB}}$ & $\begin{array}{l}1.07 \pm \\
0.02^{\mathrm{aB}}\end{array}$ \\
\hline 11 & 21.00 & 328 & 461 & $285(100)$ & Kaempferol-O-glucuronide ${ }^{4}$ & nd & $\operatorname{tr}$ & $\operatorname{tr}$ & $\operatorname{tr}$ & $\operatorname{tr}$ & $\operatorname{tr}$ \\
\hline 12 & 22.32 & 345 & 579 & $301(100)$ & $\begin{array}{l}\text { Quercetin-O-deoxyhexoside- } \\
O \text {-pentoside }\end{array}$ & $\operatorname{tr}$ & $\operatorname{tr}$ & $\operatorname{tr}$ & $\operatorname{tr}$ & $\operatorname{tr}$ & nd \\
\hline 13 & 23.33 & $\begin{array}{l}269 / \\
\operatorname{sh} 348\end{array}$ & 507 & $345(100)$ & Spinacetin-O-hexoside ${ }^{4}$ & $\operatorname{tr}$ & $\operatorname{tr}$ & $\operatorname{tr}$ & $\operatorname{tr}$ & $\operatorname{tr}$ & $\operatorname{tr}$ \\
\hline 14 & 26.46 & $\begin{array}{l}265 / \\
\operatorname{sh} 342\end{array}$ & 563 & $285(100)$ & $\begin{array}{l}\text { Kaempferol-O-deoxyhexoside- } \\
O \text {-pentoside }\end{array}$ & $\operatorname{tr}$ & $\begin{array}{l}0.43 \pm \\
0.02\end{array}$ & $\operatorname{tr}$ & $\operatorname{tr}$ & $\operatorname{tr}$ & nd \\
\hline 15 & 30.11 & 336 & 591 & $\begin{array}{l}\text { 283(100), } 269 \\
(19)\end{array}$ & Acacetin- $O$-rutinoside ${ }^{4}$ & $\operatorname{tr}$ & $\operatorname{tr}$ & nd & $\operatorname{tr}$ & $\operatorname{tr}$ & $\operatorname{tr}$ \\
\hline \multicolumn{12}{|c|}{ Anthocyanins } \\
\hline 16 & 14.92 & 523 & 655 & $\begin{array}{l}\text { 493(100), } 331 \\
(35)\end{array}$ & Malvidin-O-dihexoside ${ }^{6}$ & $\begin{array}{l}4.18 \pm \\
0.01^{\mathrm{bA}}\end{array}$ & $\begin{array}{l}4.588 \pm \\
0.001^{\mathrm{aA}}\end{array}$ & $4.102 \pm 0^{\mathrm{bB}}$ & $\begin{array}{l}4.27 \pm \\
0.01^{\mathrm{aB}}\end{array}$ & nd & nd \\
\hline 17 & 24.89 & 525 & 493 & $331(100)$ & Malvidin-3-O-glucoside $^{6}$ & $\begin{array}{l}4.37 \pm \\
0.02^{\mathrm{bA}}\end{array}$ & $\begin{array}{l}5.08 \pm \\
0.02^{\mathrm{aB}}\end{array}$ & $\begin{array}{l}4.757 \pm \\
0.001^{\mathrm{bA}}\end{array}$ & $\begin{array}{l}6.19 \pm \\
0.05^{\mathrm{aA}}\end{array}$ & $\begin{array}{l}4.096 \pm \\
0.002^{\mathrm{bA}}\end{array}$ & $\begin{array}{l}5.00 \pm \\
0.01^{\mathrm{aB}}\end{array}$ \\
\hline 18 & 35.18 & 524 & 463 & $331(100)$ & Malvidin- $O$-pentoside ${ }^{6}$ & nd & nd & $\begin{array}{l}4.025 \pm \\
0.001^{\mathrm{b}}\end{array}$ & $\begin{array}{l}4.12 \pm \\
0^{\mathrm{aA}}\end{array}$ & nd & $\begin{array}{l}4.002 \pm \\
0.004^{\mathrm{B}}\end{array}$ \\
\hline \multicolumn{6}{|c|}{$\Sigma$ Non-anthocyanin phenolic compounds } & $\begin{array}{l}25.89 \pm \\
0.03^{\text {bB }}\end{array}$ & $\begin{array}{l}28.54 \pm \\
0.04^{\mathrm{aA}}\end{array}$ & $\begin{array}{l}26.85 \pm \\
0.02^{\mathrm{bA}}\end{array}$ & $\begin{array}{l}27.07 \pm \\
0.02^{\mathrm{aB}}\end{array}$ & $\begin{array}{l}17.09 \pm \\
0.01^{\mathrm{bC}}\end{array}$ & $\begin{array}{l}17.34 \pm \\
0.07^{\mathrm{aC}}\end{array}$ \\
\hline \multicolumn{6}{|c|}{$\Sigma$ Anthocyanin phenolic compounds } & $\begin{array}{l}8.55 \pm \\
0.01^{b B}\end{array}$ & $\begin{array}{l}9.66 \pm \\
0.02^{\mathrm{aB}}\end{array}$ & $\begin{array}{l}12.884 \pm \\
0.002^{\mathrm{bA}}\end{array}$ & $\begin{array}{l}14.58 \pm \\
0.04^{\mathrm{aA}}\end{array}$ & $\begin{array}{l}4.096 \pm \\
0.002^{\mathrm{bC}}\end{array}$ & $\begin{array}{l}9.00 \pm \\
0.01^{\mathrm{aC}}\end{array}$ \\
\hline \multicolumn{6}{|c|}{$\Sigma$ Phenolic compounds } & $\begin{array}{l}34.44 \pm \\
0.05^{\text {bB }}\end{array}$ & $\begin{array}{l}38.20 \pm \\
0.05^{\mathrm{aB}}\end{array}$ & $\begin{array}{l}39.73 \pm \\
0.02^{\mathrm{bA}}\end{array}$ & $\begin{array}{l}41.64 \pm \\
0.02^{\mathrm{aA}}\end{array}$ & $\begin{array}{l}21.18 \pm \\
0.01^{b C}\end{array}$ & $\begin{array}{l}26.34 \pm \\
0.08^{\mathrm{aC}}\end{array}$ \\
\hline
\end{tabular}

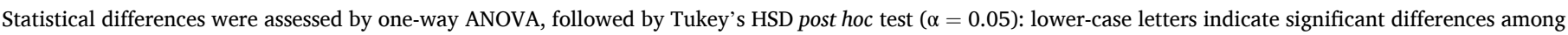

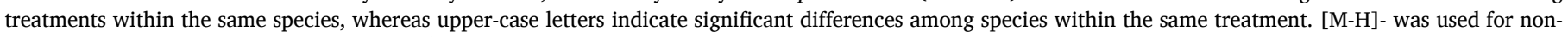

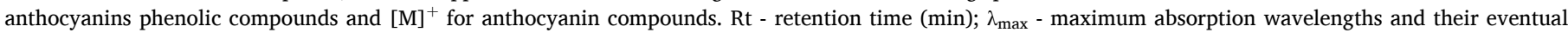

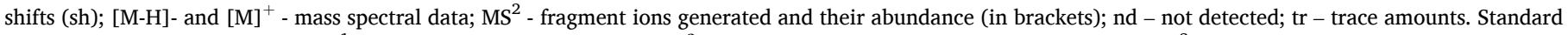

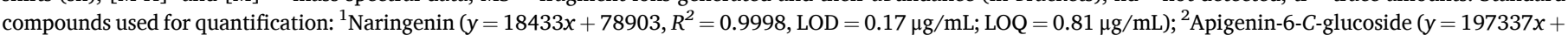

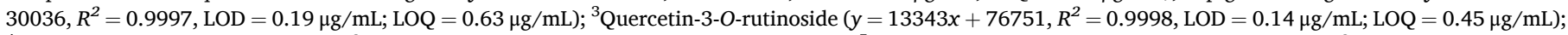

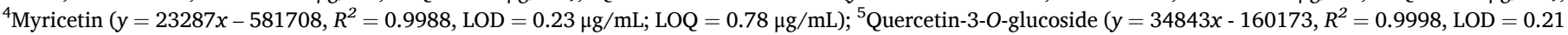
$\mu \mathrm{g} / \mathrm{mL} ; \mathrm{LOQ}=0.71 \mu \mathrm{g} / \mathrm{mL}) ;{ }^{6}$ Peonidin-3-O-glucoside $\left(y=151438 x-3 \mathrm{E}+06, R^{2}=0.9977, \mathrm{LOD}=0.12 \mu \mathrm{g} / \mathrm{mL} ; \mathrm{LOQ}=0.39 \mu \mathrm{g} / \mathrm{mL}\right)$. 


\subsubsection{Statistical analysis}

All determinations and assays were carried out in triplicate, and results were expressed as the mean \pm standard deviation (SD). Statistical analysis was performed by using the STATISTICA v.12 software (StatSoft Inc., 2014, OK, USA). Firstly, to meet the requirements for the performance of analysis of variance (ANOVA) the normality of residuals and homoscedasticity were assessed by conducting the Saphiro-Wilk's and Levene's tests, respectively. Then, one-way ANOVA was carried out to evaluate statistical differences between treatments, followed by Tukey's HSD post hoc test. Statistical differences with respect to positive controls were evaluated by Student's $t$-test The significance level was adjusted at $\alpha=0.05$ in all cases.

\section{RESULTS AND DISCUSSION}

\subsection{Identification and quantification of phenolic compounds}

The results from the analysis performed by HPLC-DAD-ESI/MS ${ }^{\mathrm{n}}$ on the hydroethanolic extracts of Bryophyllum cultured in vitro are presented in Table 1. A total of 18 flavonoids, grouped as non-anthocyanin and anthocyanin phenolic compounds, were tentatively identified by this chromatographic method: 1 flavanone (peak 1), 2 flavones (peaks 2 and 15), 12 flavonols (peaks 3 to 14), and 3 anthocyanins (peaks 16 to 18).

The main non-anthocyanin phenolic compounds reported on the three Bryophyllum species were flavonol glycosides (peaks 3 to 14), mainly represented by myricetin glycosides (peaks 4 to 8 ). Peaks 4 to 8 exhibit a DAD and an ion fragmentation pattern coherent with myricetin glycoside derivatives. All five compounds revealed a major $\mathrm{MS}^{2}$ ion at $\mathrm{m} / z 317$, characteristic of an ionized myricetin. For peaks 4 and 5 , the loss of an hexosyl (-162 u) and deoxyhexosyl (-146 u) moieties, was observed, being assigned as myricetin-3-O-glucoside (in comparison with commercial standard) and myricetin-O-deoxyhexoside, respectively. Peaks 6 to 8revealed the same pseudo-molecular ion $[\mathrm{M}-\mathrm{H}]^{-}$at $\mathrm{m} / \mathrm{z} 595$ and presented only one $\mathrm{MS}^{2}$ fragment, at $\mathrm{m} / \mathrm{z} 317$ (myricetin aglycone; pentosyl residue $(-132 \mathrm{u})$ and a deoxyhexosyl moiety $(-146$ $\mathrm{u})$ ), being tentatively identified as myricetin- $O$-pentosyl-deoxyhexoside derivatives (Ghouti et al., 2018; Ziani et al., 2018).

Peaks 3, 11, and 14 presented a DAD spectrum and a $\mathrm{MS}^{2}$ fragmentation pattern coherent with kaempferol glycoside derivatives. Peak $3\left([\mathrm{M}-\mathrm{H}]^{-}\right.$at $m / z$ 725) was tentatively identified as kaempferol- $O$ deoxyhexoside-pentoside- $O$-hexoside; the fragmentation pattern in $\mathrm{MS}^{2}$ gave two ions, a minor one at $m / z 563$, suggesting the loss of a hexosyl unit $\left([(\mathrm{M}-\mathrm{H})-162]^{-}\right)$, and major at $m / z 285$, corresponding to kaempferol aglycone after the loss of both a pentosyl and a deoxyhexoside residue $[(\mathrm{M}-\mathrm{H})-132-146]^{-}$. Similarly, peak $14([\mathrm{M}-\mathrm{H}]-$ at $m / z 563$ ) was tentatively identified as kaempferol- $O$-deoxyhexoside- $O$ pentoside. Peak 11([M-H $]^{-}$at $\left.m / z 461\right)$ revealed one major ion fragment at $m / z 285$, resulting from the loss of a glucuronyl acid residue $\left([\mathrm{M}-\mathrm{H}-176]^{-}\right)$and therefore was tentatively identified as kaempferol-Oglucuronide (Barros et al., 2011; Geng et al., 2016).

Moreover, peaks 9,10 and 12 showed a DAD and MS ${ }^{2}$ fragment at $m /$ z 301, characteristic of quercetin glycoside derivatives. Peak 9 $\left([\mathrm{M}-\mathrm{H}]^{-}\right.$at $\left.m / z 549\right)$ exhibited daughter peaks at $m / z 505$ and 463 , which correspond to the loss of a malonyl moiety $[(\mathrm{M}-\mathrm{H})-44+42]^{-}$, followed by the base peak at $m / z 301$ corresponding to quercetin aglycone, after the hexosyl moiety loss $(-162 \mathrm{u})$. This compound was tentatively assigned as quercetin- $O$-malonylhexoside. Peak 10 was positively identified as quercetin-3-O-glucoside ([M-H $]^{-}$at $\left.m / z 463\right)$, in comparison with the commercial standard. Peak 12 was tentatively identified as quercetin- $O$-deoxyhexosyl- $O$-pentoside, revealing the loss of a pentosyl and a deoxyhexosyl residue $[(\mathrm{M}-\mathrm{H})-132-146]^{-}$(Ghouti et al., 2018; Ziani et al., 2018).

Finally, with respect to flavonol glycosides, peak 13 ([M-H]- at $m / z$ $507)$ was tentatively assigned to spinacetin- $O$-hexoside taking into account its fragmentation pattern (Boukhris et al., 2016). All these compounds (peaks 3 to 14) belong to the flavonol subclass, which constitutes one of the most abundant flavonoid subclasses previously described for the Bryophyllum subgenus (Fürer et al., 2013; Stefanowicz-Hajduk et al., 2020b, 2020a; Tatsimo et al., 2012).

Besides flavonol glycosides, other flavonoid subclasses were also described in the Bryophyllum extracts, including flavones, such as apigenin (peak 2) and acacetin (peak 15) glycosides, and one flavanone (peak 1; Table 1). Peak 2 was tentatively identified as apigenin- $C$ dihexoside, with a pseudo-molecular ion at $m / z 593$, and a base peak at $m / z 473[(\mathrm{M}-\mathrm{H})-120]^{-}$, a typical fragmentation of di-C-glycosyl flavones (Tahir et al., 2012). The MS ${ }^{\mathrm{n}}$ fragments at $m / z 353[(\mathrm{M}-\mathrm{H})-(120$ $+120)]^{-}$and at $m / z 383[(\mathrm{M}-\mathrm{H})-(90+120)]^{-}$indicated the presence of apigenin (mw 270) as aglycone and two hexosyl moieties (El Sayed et al., 2016; Geng et al., 2016). Peak 15([M-H $]^{-}$at $m / z$ 591) was tentatively identified as acacetin- $\mathrm{O}$-rutinoside. The $\mathrm{MS}^{2}$ analysis gave two ions, a major one at $m / z 283$, characteristic of an ionized acacetin, which suggests the loss of a rutinosyl group $\left([(\mathrm{M}-\mathrm{H})-146+162]^{-}\right)$; and a minor one at $m / z 269$, suggesting the loss of a methyl group [(M-H)$14]^{-}$, characteristic of the apigenin structure (Lin and Harnly, 2010; Parejo et al., 2004). Peak $1\left([\mathrm{M}-\mathrm{H}]^{-}\right.$at $m / z$ 449) presented a typical $\mathrm{MS}^{2}$ fragment at $m / z$ 287, indicating a deprotonated molecule [eriodictyol-H] and the loss of one hexosyl moiety $[(\mathrm{M}-\mathrm{H})-162]^{-}$, respectively, and was tentatively identified as eriodictyol- $O$-hexoside (Pereira et al., 2013; Vallverdú-Queralt et al., 2011). Other authors reported acacetin glycosides in the leaves of B. pinnatum (Fürer et al., 2013) together with other flavones (Muzitano et al., 2006; Nascimento et al., 2015), as already detected in B. tubiflorum (Huang et al., 2013a) and B. daigremontianum (Stefanowicz-Hajduk et al., 2020a).

Concerning anthocyanins, only malvidin glycosides were identified in the leaf extracts of in vitro-cultured Bryophyllum spp. (peaks 16 to 18; Table 1). Peaks $\mathbf{1 6}$ to $\mathbf{1 8}$ were tentatively identified as glycosidic forms of anthocyanidins found in plants; the $\mathrm{MS}^{2}$ fragment at $m / z 331$ is the typical base peak of malvidin derivatives. Peak 16([M-H $]^{-}$at $\left.m / z 655\right)$ presented a consecutive loss of two hexosyl moieties [(M-H)-162 $162]^{-}$and was tentatively identified as malvidin-O-dihexoside. Peak 17 $\left([\mathrm{M}-\mathrm{H}]^{-}\right.$at $m / z 493$ ) exhibited a base peak at $m / z 331$, corresponding to the loss of an hexosyl moiety $(-162 \mathrm{u})$, being assigned as malvidin-3-Oglucoside. Whereas, peak $18\left([\mathrm{M}-\mathrm{H}]^{-}\right.$at $\left.m / z 463\right)$ revealed the loss of a pentosyl residue $[(\mathrm{M}-\mathrm{H})-132]^{-}$, being identified as malvidin- $O$-pentoside (Flamini, 2013). These compounds are associated with flower pigmentation of other species belonging to the Kalanchoe genus, together with other anthocyanins, such as peonidin and delphinidin (Nielsen et al., 2005). However, they have also been produced in root cultures (Góraj-Koniarska et al., 2015). The presence of anthocyanins in the leaves of Bryophyllum spp. might be responsible for the dark, pigmented strands located in the abaxial leaf surface of these plants, as suggested by other authors (Casanova et al., 2020). This hypothesis is reinforced by the presence of idioblasts found in the leaf structure of $B$. daigremontianum and B. tubiflorum, considered cell reservoirs for phenolic compounds (Casanova et al., 2020; Chernetskyy et al., 2018).

Regarding the quantification of phenolic compounds, culture media composition and species were two significant factors affecting the accumulation of the different compounds (Table 1). As a general rule, the macronutrient reduction on $1 / 2 \mathrm{MS}$ caused a significant positive effect ( $\mathrm{p}<0.05$ ) on the accumulation of phenolic compounds, including both non-anthocyanins and anthocyanins in all species (Table 1), due to a potential induction of phenolic compound biosynthesis caused by nutritional stress.

Myricetin glycosides were the non-anthocyanin flavonoids found in highest concentrations, with a maximum value of $5.62 \mathrm{mg} \mathrm{g}^{-1}$ in $B$. daigremontianum cultured on $1 / 2 \mathrm{MS}$, corresponding to the compound myricetin-O-pentosyl deoxyhexoside (peak 6; Table 1 ). These results are in line with the previously reported contents for Bryophyllum spp. cultured in vitro, in which macronutrient reduction led to an increased accumulation of phenolic compounds, being $B$. daigremontianum the species showing the highest accumulation of flavonoids (García-Pérez 
et al., 2020b). Such nutrient reduction can be seen as a form of abiotic stress, considered as nutritional stress, which results in the induction of secondary metabolite biosynthesis (García-Pérez et al., 2020b). As it was shown for low nitrogen, potassium, and phosphate concentrations (Blasco et al., 2018; Cramer et al., 2011), the phenylpropanoid biosynthetic pathway was enhanced via the modulation of key biosynthetic genes, such as phenylalanine ammonia lyase (PAL) and chalcone synthase (CHS) (Sharma et al., 2019). In the case of in vitro-cultured Bryophyllum spp., ammonium was predicted to promote the accumulation of phenolic compounds, as a result of the application of artificial intelligence tools (García-Pérez et al., 2020b), being also a critical factor on plant growth (García-Pérez et al., 2020d). This stress-induced overproduction of secondary metabolites is called elicitation, and was previously reported for Bryophyllum spp. (García-Pérez et al., 2019b).

Similarly, in the specific case of anthocyanins, their concentrations significantly increased $(\mathrm{p}<0.05)$ by nutritional stress in all species (peaks 16-18; Table 1). Although the highest values were found on $B . \times$ houghtonii cultured on 1/2MS, showing a concentration of $6.19 \mathrm{mg} \mathrm{g}^{-1}$ for malvidin- $O$-hexoside (peak 17; Table 1 ), the most significant effect of nutrient stress was observed on B. tubiflorum, with a $54.4 \%$ increase (from 4.09 to $9.00 \mathrm{mg} \mathrm{g}^{-1}$ for anthocyanin phenolic compounds, Table 1). These findings reinforce the hypothesis that macronutrients present a species-dependent narrow range of efficacy, which should be optimized in order to meet specific requirements for every genotype (Castro et al., 2018; García-Pérez et al., 2020d).

The highest values for total phenolics were presented by $B . \times$ houghtonii, $41.64 \mathrm{mg} \mathrm{g}^{-1}$ under nutritional stress (1/2MS; Table 1). However, the strongest effect of nutritional reduction was observed for B. tubiflorum, showing a $19.6 \%$ increase (Table 1). This speciesdependent behavior for phenolic accumulation was previously reported for Bryophyllum cultured in vitro (García-Pérez et al., 2020a, 2020b), suggesting that even genetically close species show different requirements for several physiological features, as it was also noted for other physiological features, such as in vitro growth and organogenesis (García-Pérez et al., 2020d, 2020e).

\subsection{In vitro biological activities}

\subsubsection{Antioxidant activity}

Table 2 shows the results for the in vitro antioxidant activity of Bryophyllum extracts through the two methods employed (TBARS and OxHLIA). The results from TBARS assay were given as $\mathrm{IC}_{50}$, which indicates the extract concentration required to prevent by $50 \%$ the malondialdehyde formation throughout the $\mathrm{H}^{+}$donation to lipid radicals. In parallel, the results for OxHLIA assay were also given as $\mathrm{IC}_{50}$, which indicates the extract concentration needed to protect the $50 \%$ of erythrocyte population. Hemolysis was induced by the free-radical initiator 2,2'-azobis(2-amidinopropane) dihydrochloride (AAPH) and antioxidant activity was measured at $\Delta t=60 \mathrm{~min}$, in order to allow the performance of all compounds present in the extracts, which can show different action ranges along time (Lockowandt et al., 2019). In both cases, lower $\mathrm{IC}_{50}$ values correspond to higher antioxidant activity of plant extracts.

As it can be seen in Table 2, the highest antioxidant activity was reported to extracts from plants cultured under nutritional stress (cultured on 1/2MS medium) in all species for both TBARS and OxHLIA assays, except for B. tubiflorum in OxHLIA. These findings correlate to the observed results for phenolic composition of Bryophyllum extracts, which suggest that phenolic compounds, such as myricetin and malvidin glycosides, are responsible for this antioxidant activity, as previously reported for both compounds (Barzegar, 2016; Huang et al., 2016). Specifically, the mechanism of action of these compounds has been associated to free-radical scavenging activity, due to their ability to donate $\mathrm{H}^{+}$and/or e- with the aim of forming more stable radicals (Heim et al., 2002).

According to the results for TBARS, the $\mathrm{IC}_{50}$ values for $B . \times$ houghtonii cultured on $1 / 2 \mathrm{MS}\left(27.7 \mu \mathrm{g} \mathrm{mL}^{-1}\right)$ were only 5.2 -fold higher than the positive control, $5.4 \mu \mathrm{g} \mathrm{mL}{ }^{-1}$, represented by the artificial antioxidant Trolox, whereas the results for $B$. daigremontianum and B. tubiflorum were significantly higher, $45 \mu \mathrm{g} \mathrm{mL} L^{-1}$ and $77 \mu \mathrm{g} \mathrm{mL}$, respectively (Table 2). It is noteworthy that Trolox is a single, artificial molecule with enhanced antioxidant activity, whereas plant extracts contain a heterogenous composition of phytoconstituents that may interact either positively or negatively, leading to different rates of antioxidant activity (Tsao and Deng, 2004).

Similarly, in the case of OxHLIA, the same patterns were observed, being the extracts from $B . \times$ houghtonii cultured on $1 / 2 \mathrm{MS}$ the ones

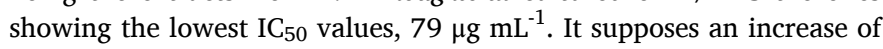
$28.8 \%$ and $30.7 \%$ in the antioxidant activity, with respect to their counterparts for $B$. daigremontianum and $B$. tubiflorum, respectively (Table 2). Again, the positive control reached significantly higher values $\left(19 \mu \mathrm{g} \mathrm{mL}{ }^{-1}\right)$.

The results for both antioxidant assays are in accordance to the previous knowledge provided by in vitro-cultured Bryophyllum spp. A

Table 2

Antioxidant, cytotoxic, hepatotoxic and anti-inflammatory activity of Bryophyllum extracts.

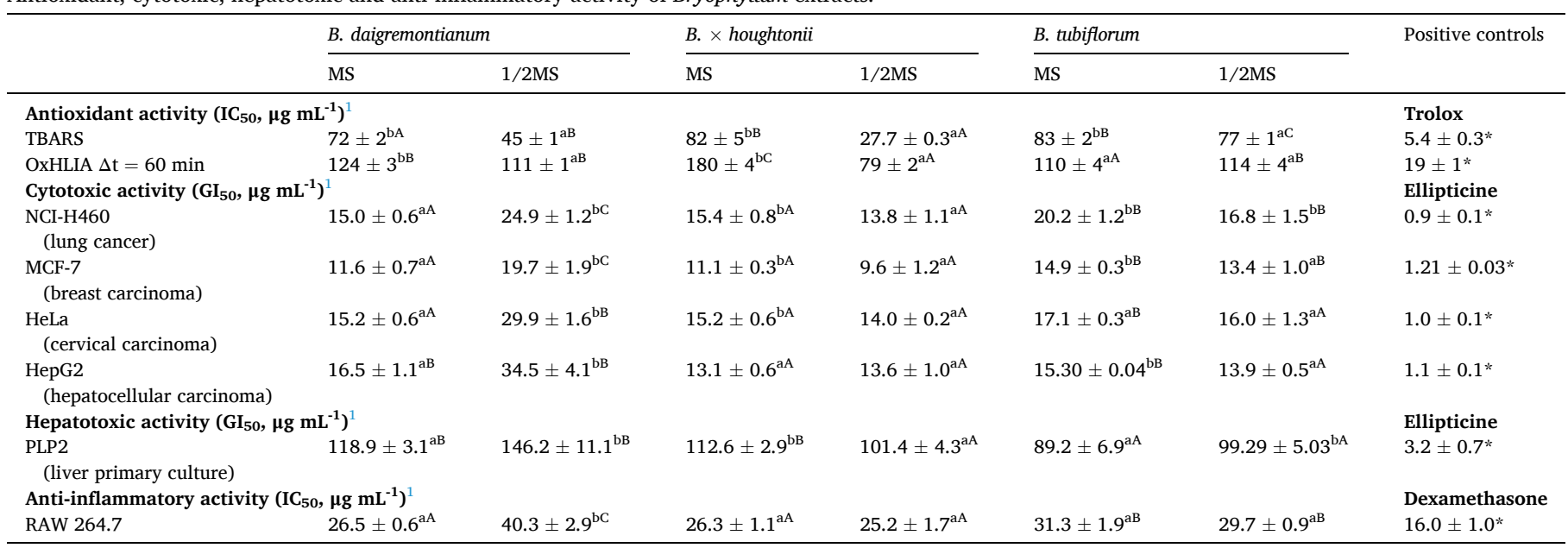

Statistical differences were assessed by one-way ANOVA, followed by Tukey's HSD post hoc test $(\alpha=0.05)$ : lower-case letters indicate significant differences among treatments within the same species, whereas upper-case letters indicate significant differences among species within the same treatment. Asterisks $(*)$ indicate statistical differences between positive controls and every treatment according to Student's t-test $(\alpha=0.05)$.

${ }^{1}$ Note: lower $\mathrm{IC}_{50}$ and $\mathrm{GI}_{50}$ values correspond to higher antioxidant activity. 
reduction in the macronutrient concentration of the culture media caused a significant 2.5-fold increase in the antioxidant activity, determined by the 2,2-diphenyl-picrylhidrazyl (DPPH) method, which was more evident in the case of $B$. $\times$ houghtonii (García-Pérez et al., 2020a, 2020b, 2019a). In fact, it was recently demonstrated that extracts from in vitro-cultured $B . \times$ houghtonii effectively prevent lipid oxidation on food models, such as omega-3 enriched fish oil-in-water emulsions (García-Pérez et al., 2020a).

A number of phytochemical reports have highlighted the antioxidant potential of different Bryophyllum species grown ex vitro and found higher $\mathrm{IC}_{50}$ values than the species employed in this work for TBARS assay, i.e.: $134.56 \mu \mathrm{g} \mathrm{m}^{-1}$ for B. pinnatum (Mohan et al., 2012). This suggests that the establishment of plant in vitro culture emerges as an efficient strategy to enhance the antioxidant potential of Bryophyllum spp., as demonstrated for B. daigremontianum, B. $\times$ houghtonii and B. tubiflorum.

\subsubsection{Cytotoxic and hepatotoxic activity}

The results obtained for the cytotoxic activity of hydroethanolic Bryophyllum extracts against four different human cancer cell lines are shown in Table 2. The values for cytotoxic activity were expressed as $\mathrm{GI}_{50}$, which indicates the extract concentration (in $\mu \mathrm{g} \mathrm{mL}^{-1}$ ) required to inhibit cell growth by $50 \%$. In all cell lines tested, the extracts belonging to $B . \times$ houghtonii cultured on $1 / 2 \mathrm{MS}$ showed the highest cytotoxic activity, although no significant differences $(p>0.05)$ were found for HeLa and HepG2 between $B . \times$ houghtonii and B. tubiflorum (Table 2). In contrast, the extracts from $B$. daigremontianum showed the highest activity for MS-grown plants (Table 2). This differential observation may indicate that, besides phenolic compounds, there are other families of secondary metabolites that contribute to the development of cytotoxic activity in this species, i.e.: bufadienolides. Bufadienolides are C-24 steroidal compounds, widely distributed among Bryophyllum subgenus, that show a potent cytotoxic activity against a series of human cancer cell lines (García-Pérez et al., 2019, 2020c). However, the flavonoids present in Bryophyllum extracts, such as myricetin and malvidin, also present an associated cytotoxic activity, establishing a close relationship between plant phenolic content (Table 1) and cytotoxicity (Table 2), in agreement with previous results (Hyun and Chung, 2004; Semwal et al., 2016).

Regarding cancer cell lines, MCF-7 (breast carcinoma) was the most sensitive to Bryophyllum extracts, showing the lowest $\mathrm{GI}_{50}$ values for all species, mostly $B$. $\times$ houghtonii $\left(9.6 \mu \mathrm{g} \mathrm{mL}^{-1}\right.$; Table 2$)$. The rest of cell lines tested, including NCI-H460 (lung cancer), HeLa (cervix carcinoma) and HepG2 (hepatocellular carcinoma) presented a similar sensitivity against $B . \times$ houghtonii cultured on $1 / 2 \mathrm{MS}$, with $\mathrm{GI}_{50}$ values ranging $13.6-14.0 \mu \mathrm{g} \mathrm{mL}^{-1}$. These results show the same patterns as reported in recent reports conducted on $B$. daigremontianum cultured ex vitro, in which the cytotoxicity against MCF-7 $\left(43.6 \mu \mathrm{g} \mathrm{mL}^{-1}\right)$ was significantly higher than against HeLa cell line $\left(100 \mu \mathrm{g} \mathrm{m}^{-1}\right.$ ) (Stefanowicz-Hajduk et al., 2020a). Several authors demonstrated that kaempferol and myricetin, found on Bryophyllum spp. hydroethanolic extracts, showed a potent cytotoxic effect against MCF-7 cell line, thus suggesting that both molecules may be the major responsible for such effects observed for this cell line (Jiao and Zhang, 2016; Srinivas Raghavan et al., 2015). Specifically, myricetin has been shown to exert a 7-fold higher cytotoxic activity against MCF-7 than the HeLa cell line (Semwal et al., 2016). In addition, the cytotoxic activity of Bryophyllum spp. is well-known for a series of different species, including $B$. daigremontianum, as described earlier, B. $\times$ houghtonii (Supratman et al., 2001) and B. tubiflorum (Hsieh et al., 2016). Nevertheless, to the best of authors' knowledge, this is the first work applying in vitro culture methodology as a solution to improve the phytochemical potential of Bryophyllum spp., in terms of cytotoxic activity.

Hepatotoxicity was assessed by the use of one non-tumor PLP2 porcine liver cell culture and results are shown in Table 2. Ellipticine was selected as the positive control, as it occurred for cytotoxic activity: despite its efficacy as cytotoxic agent $\left(0.9-1.2 \mu \mathrm{g} \mathrm{mL}{ }^{-1}\right)$ (Stiborová et al., 2011), ellipticine also caused the highest toxicity against porcine liver cell line PLP2 (3.2 $\mu \mathrm{g} \mathrm{mL}^{-1}$; Table 2). In this sense, Bryophyllum extracts showed a markedly lower hepatotoxicity, being MS-grown $B$. tubiflorum the species whose the extracts caused the highest hepatotoxicity, $89.2 \mu \mathrm{g} \mathrm{mL}^{-1}$, with 27.9 -fold higher $\mathrm{GI}_{50}$ values than ellipticine (Table 2). This lower hepatotoxicity associated to Bryophyllum extracts may be explained in the basis of their hepatoprotective properties, as demonstrated in both in vitro and in vivo assays (Yadav and Dixit, 2003).

\subsubsection{Anti-inflammatory activity}

The results obtained for the anti-inflammatory activity of Bryophyllum extracts are displayed in Table 2. Anti-inflammatory activity was assessed by $\mathrm{IC}_{50}$ values $\left(\mu \mathrm{g} \mathrm{mL}^{-1}\right)$, which represent the extract concentration required to inhibit by $50 \%$ the NO production by LPSinduced macrophages. Our results show that $B . \times$ houghtonii presented the highest anti-inflammatory activity regardless of the composition of culture media, ranging $25.2-26.3 \mu \mathrm{g} \mathrm{mL} \mathrm{mL}^{-1}$ together with MS-cultured $B$. daigremontianum extracts, whereas $B$. tubiflorum extracts promoted a significantly lower activity (Table 2). However, in all cases, dexamethasone, used as positive control, showed a more potent anti-inflammatory activity than Bryophyllum extracts. These patterns in the results are likely related to those from cytotoxic activity (Table 2). This observation may suggest a crosstalk between inflammation and cancer proliferation signaling pathways, in which macrophages play a relevant role, as demonstrated in many epidemiological studies (Elinav et al., 2013; García-Pérez et al., 2019). Therefore, the present work provides enough evidence showing that Bryophyllum phytochemical potential is developed by a wide range of bioactivities. Both myricetin and malvidin, as the most relevant phenolic compounds identified in Bryophyllum spp., were found to exert a potent effect on the LPS-induced NO biosynthesis by macrophages, via the inhibition of nuclear factor-kappa B (NF-кB) (Bognar et al., 2013; Hämäläinen et al., 2007). Previous phytochemical studies have pointed at flavonoids from $B$. tubiflorum as anti-inflammatory agents, showing different rates of activity depending on the compounds, whose $\mathrm{IC}_{50}$ values range between $4.5-19.6 \mu \mathrm{gL}^{-1}$ (Huang et al., 2013b). Furthermore, the ethanolic extracts from B. pinnatum maintained their anti-inflammatory activity when transferred to in vivo murine models (Tanko, 2012), thus suggesting a promising approach for their application from in vitro to in vivo conditions.

\subsubsection{Antimicrobial activity}

Table 3 includes the results for antimicrobial activity, for both antibacterial (expressed as MIC and $\mathrm{MBC}$ ) and antifungal activities (expressed as MIC and MFC). Concerning the antibacterial activities, differential results were obtained depending on the genotype employed. Bacillus cereus was the strain showing the highest sensitivity against Bryophyllum extracts (MIC $=0.9 \mathrm{mg} \mathrm{mL}^{-1}$ for $1 / 2 \mathrm{MS}$-cultured B. daigremontianum extracts), together with other Gram-positive strains, such as Listeria monocytogenes and Staphylococcus aureus in a lesser extent (MIC $=1.8$ and $3.6 \mathrm{mg} \mathrm{mL}^{-1}$, respectively). On the other hand, Escherichia coli was the Gram-negative strain showing the highest sensitivity against Bryophyllum extracts (MIC $=1.8 \mathrm{mg} \mathrm{mL}^{-1}$ for $1 / 2 \mathrm{MS}$ cultured B. daigremontianum extracts), whereas Enterobacter cloacae and Salmonella Typhimurium showed an increased resistance (MIC $=7.2 \mathrm{mg}$ $\mathrm{mL}^{-1}$ ), both providing identical results (Table 3). The MBC values were in accordance with the results shown for MIC (Table 3).

In the case of antifungal activities, differential results were also obtained depending on the genotype employed. Our results reflected a differential efficiency towards fungal strains: Aspergillus ochraceus showed the greatest sensitivity against all the extracts, with MIC values ranging between $0.5 \mathrm{mg} \mathrm{mL}^{-1}$, for $B$. daigremontianum and B. tubiflorum, and $0.8 \mathrm{mg} \mathrm{mL}{ }^{-1}$, for $B . \times$ houghtonii (Table 3). In addition, $B$. daigremontianum and $B . \times$ houghtonii also showed an enhanced antifungal activity against Aspergillus fumigatus and Penicillium funiculosum 
Table 3

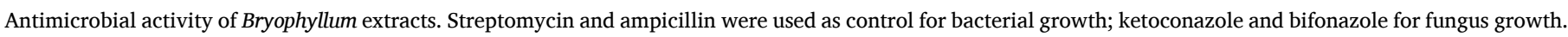

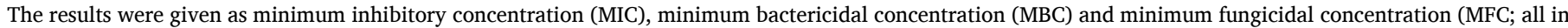
$\mathrm{mg} \mathrm{mL}^{-1}$ ).

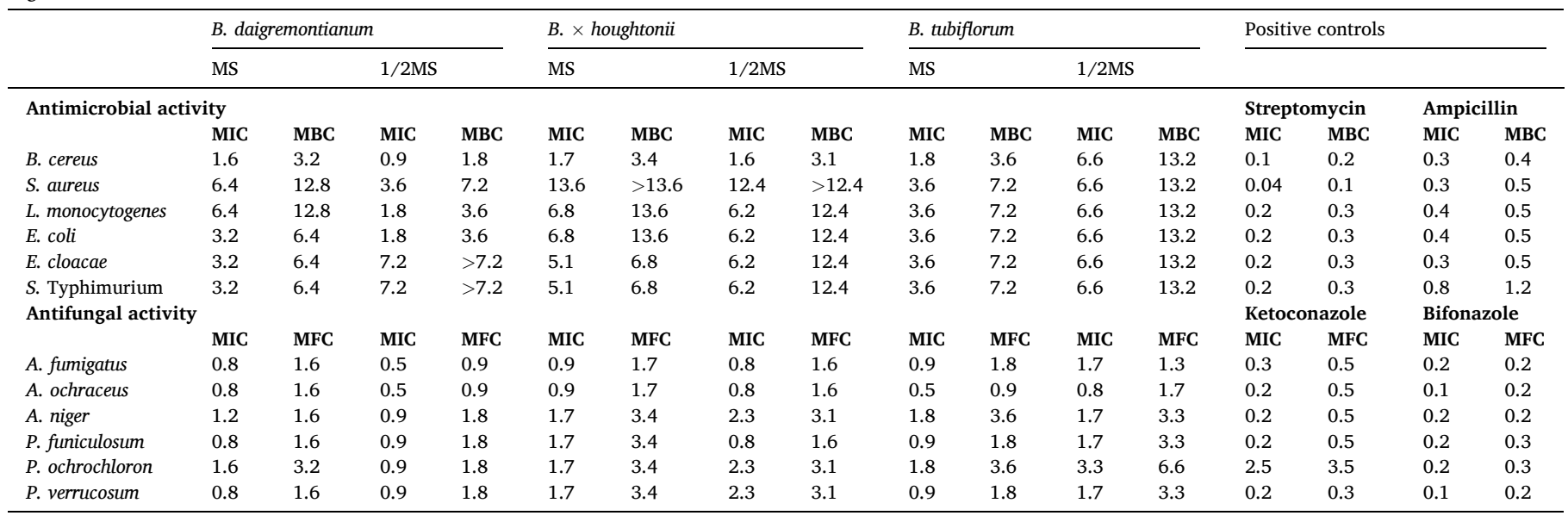

(MIC $=0.8 \mathrm{mg} \mathrm{mL}^{-1}$ in all cases). The MFC values are in accordance with the results shown for MIC (Table 3). In all cases, positive controls showed greater antimicrobial activity than Bryophyllum extracts, probably due to the existence of heterogenous compounds with complex interactions that modulate such bioactivity, as stated above.

Myricetin, as the most prevalent non-anthocyanin flavonoid on Bryophyllum spp. aerial parts, has been shown to exert a potent antimicrobial activity. Specifically, this flavonol was found to exhibit a potent inhibition of both DNA and RNA polymerases in E. coli (Ong and Khoo, 1997 ) and showed a moderate growth inhibition against $S$. aureus and digestive-related bacteria (Xu and Lee, 2001), being our results in line with the previous literature. Malvidin, as the most representative anthocyanin in Bryophyllum spp., has also been associated to antimicrobial activity, including both antibacterial and antifungal activities (Cisowska et al., 2011). Thus, it is suggested that the phenolic constituents of Bryophyllum extracts are responsible for the inhibition of both bacterial and fungal growth. Previous works already reported that Bryophyllum extracts have a significant antimicrobial activity, as demonstrated by $B$. daigremontianum, showing a moderate activity against B. cereus, S. aureus, E. coli and A. niger (Anisimov et al., 2009; Nahar et al., 2008). The efficiency of Bryophyllum against enterobacteria shows a general pattern, showing an enhanced antibacterial activity, as demonstrated for B. mortagei and B. fedtschenkoi (Richwagen et al., 2019). In parallel, other authors have outlined the efficiency of Bryophyllum extracts against another relevant bacteria, such as Pseudomonas aeruginosa, as found for B. daigremontianum (Nahar et al., 2008) and B. pinnatum (Okwu and Nnamdi, 2011).

\section{CONCLUSIONS}

In this work, the establishment of plant in vitro culture was performed as an effective strategy to enhance the phytochemical potential of three medicinal plant species belonging to the subgenus Bryophyllum. The identification and quantification of phenolic compounds showed that these species are a valuable source of flavonols and anthocyanins. Concerning the genotype, the species $B$. daigremontianum showed the highest rates of myricetin glycosides, whereas $B . \times$ houghtonii presented the highest rates of malvidin glycosides. In both cases, the use of culture media formulation with a reduced macronutrient concentration, as an approach to induce nutritional stress, led to the accumulation of such compounds through a phenomenon called elicitation. To provide insight into the phytochemical potential of in vitro-cultured Bryophyllum spp., different biological activities were analyzed. According to both antioxidant activity assays employed in this work, the extracts from $B . \times$ houghtonii cultured under nutritional stress, showed the highest rates of antioxidant activity. The same extracts showed the highest cytotoxic activity, with an enhanced effectiveness towards MCF-7 breast carcinoma cell line. Moreover, the anti-inflammatory activity presented the same patterns as observed for antioxidant and cytotoxic activity, in which extracts from $B . \times$ houghtonii under nutritional stress exhibited the highest activity. The results displayed in this work suggest that the highest rates of antioxidant, cytotoxic and anti-inflammatory activities attributed to $B$. $\times$ houghtonii cultured under nutritional stress are caused by the accumulation of anthocyanins, specifically malvidin glycosides. In this way, thanks to their associated antioxidant, cytotoxic and antiinflammatory bioactivities, these anthocyanin-rich extracts, are considered as promising candidates to promote an integrative effectiveness against the cancer-related phenomena, as it is the case of oxidative stress, inflammation and malignant cell proliferation, closely related during the initiation of carcinogenic process. Finally, concerning antimicrobial activity, the extracts obtained from $B$. daigremontianum cultured under nutritional stress showed the highest activity against both Gram-positive bacteria, such as B. cereus and L. monocytogenes, and Gram-negative bacteria, including $E$. coli, together with some fungal Aspergillus and Penicillium species. Overall, this study shed light about the phytochemical potential of an unexplored plant subgenus, by providing evidence for considering in vitro-cultured Bryophyllum spp. as a valuable source of bioactive compounds to be applied in different biobased industrial areas.

\section{Funding}

This work was funded by Xunta de Galicia through Cluster of Agricultural Research and Development (CITACA Strategic Partnership, grant number ED431E 2018/07) and "Red de Uso Sostenible de los Recursos Naturales y Agroalimentarios" (REDUSO, grant number ED431D2017/18). The authors are also grateful to the Foundation for Science and Technology (FCT, Portugal) for financial support through national funds FCT/MCTES to CIMO (UIDB/00690/2020); L. Barros, M. I. Dias, C. Pereira and R. Calhelha are grateful to FCT, P.I., through the institutional scientific employment program-contract for their research contacts; to FEDER-Interreg España-Portugal programme for financial support through the project TRANSCoLAB (0612_TRANS_CO_LAB_2_P). This work has been supported by Ministry of Education, Science and Technological Development of Republic of Serbia (451-03-68/2020-14/ 200007). 


\section{CRediT authorship contribution statement}

Pascual García-Pérez: Methodology, Data curation, Formal analysis, Writing - original draft, Writing - review \& editing. Manuel Ayuso: Methodology, Data curation, Writing - original draft, Writing - review \& editing. Eva Lozano-Milo: Methodology, Writing - review \& editing. Carla Pereira: Methodology, Writing - original draft, Writing - review \& editing. Maria Inês Dias: Methodology, Writing - original draft, Writing - review \& editing. Marija Ivanov: Methodology, Writing - review \& editing. Ricardo C. Calhelha: Methodology, Writing - review \& editing. Marina Soković: Methodology, Data curation, Writing - review \& editing. Isabel C.F.R. Ferreira: Funding acquisition, Project administration, Writing - review \& editing. Lillian Barros: Conceptualization, Data curation, Formal analysis, Funding acquisition, Project administration, Writing - original draft, Writing - review \& editing. Pedro P. Gallego: Conceptualization, Funding acquisition, Project administration, Writing - review \& editing.

\section{Declaration of Competing Interest}

The authors declare that they have no known competing financial interests or personal relationships that could have appeared to influence the work reported in this paper.

\section{Acknowledgements}

The authors acknowledge the Spanish Ministry of Education for the FPU grant awarded to Pascual García-Pérez (FPU15/04849) and ADICAM research center for kindly providing the plant material.

\section{References}

Anisimov, M.M., Gerasimenko, N.I., Chaikina, E.L., Serebryakov, Y.M., 2009. Biologica activity of metabolites of the herb Kalanchoe daigremontiana (Hamet de la Bathie) Jacobs et Perr. Biol. Bull. 36, 568-574. https://doi.org/10.1134/ S1062359009060041.

Barros, L., Dueñas, M., Ferreira, I.C.F.R., Maria Carvalho, A., Santos-Buelga, C., 2011. Use of HPLC-DAD-ESI/MS to profile phenolic compounds in edible wild greens from Portugal. Food Chem. 127, 169-173. https://doi.org/10.1016/j. foodchem.2011.01.009.

Barzegar, A., 2016. Antioxidant activity of polyphenolic myricetin in vitro cell- free and cell-based systems. Mol. Biol. Res. Commun. 5, 87-95. https://doi.org/10.22099/ mbrc. 2016.3651.

Bessada, S.M.F., Barreira, J.C.M., Barros, L., Ferreira, I.C.F.R., Oliveira, M.B.P.P., 2016 Phenolic profile and antioxidant activity of Coleostephus myconis (L.) Rchb.f.: An underexploited and highly disseminated species. Ind. Crops Prod. 89, 45-51. https:// doi.org/10.1016/j.indcrop.2016.04.065.

Blasco, B., Navarro-León, E., Ruiz, J.M., 2018. Oxidative stress in relation with micronutrient deficiency or toxicity. In: Hossain, M.A., Kamiya, T., Burritt, D., Tran, L.-S.P., Fujiwara, T. (Eds.), Plant Micronutrient Use Efficiency: Molecular and Genomic Perspectives in Crop Plants. Academic Press, London, UK, pp. 181-194. https://doi.org/10.1016/B978-0-12-812104-7.00011-3.

Bognar, E., Sarszegi, Z., Szabo, A., Debreceni, B., Kalman, N., Tucsek, Z., Sumegi, B. Gallyas, F., 2013. Antioxidant and anti-inflammatory effects in RAW264.7 macrophages of malvidin, a major red wine polyphenol. PLoS One 8. https://doi. org/10.1371/journal.pone.0065355.

Bogucka-Kocka, A., Zidorn, C., Kasprzycka, M., Szymczak, G., Szewczyk, K., 2016. Phenolic acid content, antioxidant and cytotoxic activities of four Kalanchoë species. Saudi J. Biol. Sci. 25, 622-630. https://doi.org/10.1016/j.sjbs.2016.01.037.

Boukhris, M.A., Destandau, É., El Hakmaoui, A., El Rhaffari, L., Elfakir, C., 2016. A dereplication strategy for the identification of new phenolic compounds from Anvillea radiata (Coss. \& Durieu). Comptes Rendus Chim. 19, 1124-1132. https:// doi.org/10.1016/j.crci.2016.05.019.

Casanova, J.M., dos Santos Nascimento, L.B., Casanova, L.M., Leal-Costa, M.V., Costa, S S., Tavares, E.S., 2020. Differential distribution of flavonoids and phenolic acids in leaves of Kalanchoe delagoensis Ecklon \& Zeyher (Crassulaceae). Microsc. Microanal. 1-8. https://doi.org/10.1017/s1431927620024344.

Castro, P.H., Lilay, G.H., Assunção, A.G.L., 2018. Regulation of micronutrient homeostasis and deficiency response in plants. In: Hossain, M.A., Kamiya, T., Burritt, D., Tran, L.-S.P., Fujiwara, T. (Eds.), Plant Micronutrient Use Efficiency: Molecular and Genomic Perspectives in Crop Plants. Academic Press, London, UK, pp. 1-15. https://doi.org/10.1016/B978-0-12-812104-7.00002-2.

Chernetskyy, M., Woźniak, A., Skalska-Kamińska, A., Żuraw, B., Blicharska, E., Rejdak, R., Donica, H., Weryszko-Chmielewska, E., 2018. Structure of leaves and phenolic acids in Kalanchoë daigremontiana Raym.-Hamet \& H. Perrier. Acta Sci. Pol. Hortorum Cultus 17, 137-155. https://doi.org/10.24326/asphc.2018.4.13.
Cisowska, A., Wojnicz, D., Hendrich, A.B., 2011. Anthocyanins as antimicrobial agents of natural plant origin. Nat. Prod. Commun. 6, 149-156. https://doi.org/10.1177/ $1934578 \times 1100600136$.

Cramer, G.R., Urano, K., Delrot, S., Pezzotti, M., Shinozaki, K., 2011. Effects of abiotic stress on plants: A systems biology perspective. BMC Plant Biol. 11, 163. https://doi. org/10.1186/1471-2229-11-163.

de Paiva, L.S., Hayashi, E.A., De Melo, G.O., Costa, S.S., Koatz, V.L.G., Nobrega, A., 2008d. Inhibition of B cell development by kalanchosine dimalate. Int. Immunopharmacol. 8, 828-835. https://doi.org/10.1016/j.intimp.2008.01.028.

Descoings, B., 2006. Le genre Kalanchoe structure et définition par Bernard Descoings. Le J. Bot. 33, 3-28.

Dias, M.I., Sousa, M.J., Alves, R.C., Ferreira, I.C.F.R., 2016. Exploring plant tissue culture to improve the production of phenolic compounds: A review. Ind. Crops Prod. 82 9-22. https://doi.org/10.1016/j.indcrop.2015.12.016.

El Sayed, A.M., Ezzat, S.M., El Naggar, M.M., El Hawary, S.S., 2016. In vivo diabetic wound healing effect and HPLC-DAD-ESI-MS/MS profiling of the methanol extracts of eight Aloe species. Rev. Bras. Farmacogn. 26, 352-362. https://doi.org/10.1016/j. bjp.2016.01.009.

Elinav, E., Nowarski, R., Thaiss, C.A., Hu, B., Jin, C., Flavell, R.A., 2013. Inflammationinduced cancer: Crosstalk between tumours, immune cells and microorganisms. Nat. Rev. Cancer 13, 759-771. https://doi.org/10.1038/nrc3611.

Flamini, R., 2013. Recent applications of mass spectrometry in the study of grape and wine polyphenols. ISRN Spectrosc. 2013, 1-45. https://doi.org/10.1155/2013/ 813563.

Fürer, K., Raith, M., Brenneisen, R., Mennet, M., Simões-Wüst, A.P., Von Mandach, U., Hamburger, M., Potterat, O., 2013. Two new flavonol glycosides and a metabolite profile of Bryophyllum pinnatum, a phytotherapeutic used in obstetrics and gynaecology. Planta Med. 79, 1565-1571. https://doi.org/10.1055/s-00331350808.

Fürer, K., Simões-Wüst, A.P., Von Mandach, U., Hamburger, M., Potterat, O., 2016. Bryophyllum pinnatum and related species used in anthroposophic medicine: Constituents, pharmacological activities, and clinical efficacy. Planta Med. 82, 930-941. https://doi.org/10.1055/s-0042-106727.

Garcês, H., Sinha, N., 2009. The "Mother of Thousands" (Kalanchoë daigremontiana): A plant model for asexual reproduction and CAM studies. Cold Spring Harb. Protoc. 4, 1-9. https://doi.org/10.1101/pdb.emo133.

Garcês, H.M.P., Koenig, D., Townsley, B.T., Kim, M., Sinha, N.R., 2014. Truncation of LEAFY COTYLEDON1 protein is required for asexual reproduction in Kalanchö̈ daigremontiana. Plant Physiol. 165, 196-206. https://doi.org/10.1104/ pp.114.237222.

García-Pérez, P., Barreal, M.E., Rojo-De Dios, L., Cameselle-Teijeiro, J.F., Gallego, P.P., 2019. Bioactive natural products from the genus Kalanchoe as cancer chemopreventive agents: A review. In: Ur-Rahman, A. (Ed.), Studies in Natural Products Chemistry, 61. Elsevier, Amsterdam, pp. 49-84.

García-Pérez, P., Losada-Barreiro, S., Bravo-Díaz, C., Gallego, P.P., 2020a. Exploring the use of Bryophyllum as natural source of bioactive compounds with antioxidant activity to prevent lipid oxidation of fish oil-in-water emulsions. Plants 9, 1012. https://doi.org/10.3390/plants9081012.

García-Pérez, P., Losada-Barreiro, S., Gallego, P.P., Bravo-Díaz, C., 2019a. Adsorption of gallic acid, propyl gallate and polyphenols from Bryophyllum extracts on activated carbon. Sci. Rep. 9, 14830. https://doi.org/10.1038/s41598-019-51322-6.

García-Pérez, P., Losada-Barreiro, S., Gallego, P.P., Bravo-Díaz, C., 2019b. Cyclodextrinelicited Bryophyllum suspension cultured cells: Enhancement of the production of bioactive compounds. Int. J. Mol. Sci. 20, 5180. https://doi.org/10.3390/ ijms20205180.

García-Pérez, P., Lozano-Milo, E., Landín, M., Gallego, P.P., 2020b. Combining medicinal plant in vitro culture with machine learning technologies for maximizing the production of phenolic compounds. Antioxidants 9, 210. https://doi.org/10.3390/ antiox9030210.

García-Pérez, P., Lozano-Milo, E., Landín, M., Gallego, P.P., 2020c. From ethnomedicine to plant biotechnology and machine learning: the valorization of medicinal plant Bryophyllum sp. Pharmaceuticals 13, 444. https://doi.org/10.3390/ph13120444.

García-Pérez, P., Lozano-Milo, E., Landin, M., Gallego, P.P., 2020d. Machine Learning unmasked nutritional imbalances on the medicinal plant Bryophyllum sp. cultured in vitro. Front. Plant Sci. 11, 576177 https://doi.org/10.3389/fpls.2020.576177.

García-Pérez, P., Lozano-Milo, E., Landin, M., Gallego, P.P., 2020e. Machine Learning technology reveals the concealed interactions of phytohormones on medicinal plant in vitro organogenesis. Biomolecules 10, 746. https://doi.org/10.3390/ biom10050746.

Geng, P., Sun, J., Zhang, M., Li, X., Harnly, J.M., Chen, P., 2016. Comprehensive characterization of C-glycosyl flavones in wheat (Triticum aestivum L.) germ using UPLC-PDA-ESI/HRMSn and mass defect filtering. J. Mass Spectrom. 51, 914-930. https://doi.org/10.1002/jms.3803.

Ghouti, D., Rached, W., Abdallah, M., Pires, T.C.S.P., Calhelha, R.C., Alves, M.J., Abderrahmane, L.H., Barros, L., Ferreira, I.C.F.R., 2018. Phenolic profile and in vitro bioactive potential of Saharan Juniperus phoenicea L. and Cotula cinerea (Del) growing in Algeria. Food Funct. 9, 4664-4672. https://doi.org/10.1039/ c8fo01392f.

Gonçalves, G.A., Soares, A.A. Correa, R.C.G., Barros, L., Haminiuk, C.W.I., Peralta, R.M. Ferreira, I.C.F.R., Bracht, A., 2017. Merlot grape pomace hydroalcoholic extract improves the oxidative and inflammatory states of rats with adjuvant-induced arthritis. Journal of Functional Foods 33, 408-418.

Góraj-Koniarska, J., Stochmal, A., Oleszek, W., Mołdoch, J., Saniewski, M., 2015. Elicitation of anthocyanin production in roots of Kalanchoe blossfeldiana by methyl jasmonate. Acta Biol. Cracoviensia Ser. Bot. 57, 141-148. https://doi.org/10.1515/ abcsb-2015-0007. 
Guimarães, R., Barros, L., Dueñas, M., Calhelha, R.C., Carvalho, A.M., Santos-Buelga, C., Queiroz, M.J.R.P., Ferreira, I.C.F.R., 2013. Nutrients, phytochemicals and bioactivity of wild Roman chamomile: A comparison between the herb and its preparations. Food Chem. 136, 718-725. https://doi.org/10.1016/j.foodchem.2012.08.025.

Hämäläinen, M., Nieminen, R., Vuorela, P., Heinonen, M., Moilanen, E., 2007. Antiinflammatory effects of flavonoids: Genistein, kaempferol, quercetin, and daidzein inhibit STAT-1 and NF- $\mathrm{kB}$ activations, whereas flavone, isorhamnetin, naringenin, and pelargonidin inhibit only NF- $\mathrm{kB}$ activation along with their inhibitory effect on $\mathrm{i}$. Mediators Inflamm. 2007 https://doi.org/10.1155/2007/45673.

Heim, K.E., Tagliaferro, A.R., Bobilya, D.J., 2002. Flavonoid antioxidants: chemistry, metabolism and structure-activity relationships. J. Nutr. Biochem. 13, 572-584. https://doi.org/10.1016/S0955-2863(02)00208-5.

Heleno, S.A., Ferreira, I.C.F.R., Esteves, A.P., Ćirić, A., Glamočlija, J., Martins, A., Soković, M., Queiroz, M.J.R.P., 2013. Antimicrobial and demelanizing activity of Ganoderma lucidum extract, p-hydroxybenzoic and cinnamic acids and their synthetic acetylated glucuronide methyl esters. Food Chem. Toxicol. 58, 95-100. https://doi. $\operatorname{org} / 10.1016 /$ j.fct.2013.04.025.

Hsieh, Y.-J., Huang, H.-S., Leu, Y.-L., Peng, K.-C., Chang, C.-J., Chang, M.-Y., 2016. Anticancer activity of Kalanchoe tubiflora extract against human lung cancer cells in vitro and in vivo. Environ. Toxicol. 31, 1663-1673.

Huang, H.C., Huang, G.J., Liaw, C.C., Yang, C.S., Yang, C.P., Kuo, C.L., Tseng, Y.H., Wang, S.Y., Chang, W. Te, Kuo, Y.H., 2013a. A new megastigmane from Kalanchoe tubiflora (Harvey) Hamet. Phytochem. Lett. 6, 379-382. https://doi.org/10.1016/j. phytol.2013.04.002.

Huang, H.C., Lin, M.K., Yang, H.L., Hseu, Y.C., Liaw, C.C., Tseng, Y.H., Tsuzuki, M., Kuo, Y.H., 2013b. Cardenolides and bufadienolide glycosides from Kalanchoe tubiflora and evaluation of cytotoxicity. Planta Med. 79, 1362-1369. https://doi.org/ 10.1055/s-0033-1350646.

Huang, W., Zhu, Y., Li, C., Sui, Z., Min, W., 2016. Effect of blueberry anthocyanins malvidin and glycosides on the antioxidant properties in endothelial cells. Oxid. Med. Cell. Longev. 2016 https://doi.org/10.1155/2016/1591803.

Hyun, J.W., Chung, H.S., 2004. Cyanidin and malvidin from Oryza sativacv. Heugjinjubyeo mediate cytotoxicity against human monocytic leukemia cells by arrest of G2/M phase and induction of apoptosis. J. Agric. Food Chem. 52, 2213-2217. https://doi.org/10.1021/jf030370h.

Jiao, D., Zhang, X.D., 2016. Myricetin suppresses p21-activated kinase 1 in human breast cancer MCF-7 cells through downstream signaling of the $\beta$-catenin pathway. Oncol. Rep. 36, 342-348. https://doi.org/10.3892/or.2016.4777.

Kolodziejczyk-Czepas, J., Stochmal, A., 2017. Bufadienolides of Kalanchoe species: an overview of chemical structure, biological activity and prospects for pharmacological use. Phytochem. Rev. 16, 1155-1171. https://doi.org/10.1007/ s11101-017-9525-1.

Lin, L.Z., Harnly, J.M., 2010. Identification of the phenolic components of chrysanthemum flower (Chrysanthemum morifolium Ramat). Food Chem. 120, 319-326. https://doi.org/10.1016/j.foodchem.2009.09.083.

Lockowandt, L., Pinela, J., Roriz, C.L., Pereira, C., Abreu, R.M.V., Calhelha, R.C., Alves, M.J., Barros, L., Bredol, M., Ferreira, I.C.F.R., 2019. Chemical features and bioactivities of cornflower (Centaurea cyanus L.) capitula: The blue flowers and the unexplored non-edible part. Ind. Crops Prod. 128, 496-503. https://doi.org/ 10.1016/j.indcrop.2018.11.059.

Mahata, S., Maru, S., Shukla, S., Pandey, A., Mugesh, G., Das, B.C., Bharti, A.C., 2012. Anticancer property of Bryophyllum pinnata (Lam.) Oken. leaf on human cervical cancer cells. BMC Complement. Altern. Med. 12, 15. https://doi.org/10.1186/1472 6882-12-15.

Milad, R., 2014. Genus Kalanchoe (Crassulaceae): a review of its ethnomedicinal, botanical, chemical and pharmacological properties. European J. Med. Plants 4, 86-104. https://doi.org/10.9734/ejmp/2014/5901.

Mohan, S.C., Balamurugan, V., Elayaraja, R., Prabakaran, A.S., 2012. Antioxidant and phytochemical potential of medicinal plant Kalanchoe pinnata. Int J Pharm Sci Res 3, 881-885.

Moon, K.B., Park, J.S., Park, Y. Il, Song, I.J., Lee, H.J., Cho, H.S., Jeon, J.H., Kim, H.S., 2020. Development of systems for the production of plant-derived biopharmaceuticals. Plants 9, 1-21. https://doi.org/10.3390/plants9010030.

Murashige, T., Skoog, F., 1962. A revised medium for rapid growth and bio assays with tobacco tissue cultures. Physiol. Plant. 15, 473-497. https://doi.org/10.1111/ j.1399-3054.1962.tb08052.x.

Muzitano, M.F., Tinoco, L.W., Guette, C., Kaiser, C.R., Rossi-Bergmann, B., Costa, S.S., 2006. The antileishmanial activity assessment of unusual flavonoids from Kalanchoe pinnata. Phytochemistry 67, 2071-2077. https://doi.org/10.1016/j. phytochem.2006.06.027.

Nahar, K., Khan, M.G.U., Rahman, M.S., Begum, B., Rashid, M.A., 2008. Antimicrobial and cytotoxic activities of Bryophyllum daigremontianum. Dhaka Univ. J. Pharm. Sci. 7, 99-101.

Narayani, M., Srivastava, S., 2017. Elicitation: a stimulation of stress in in vitro plant cell/tissue cultures for enhancement of secondary metabolite production. Phytochem. Rev. 16, 1227-1252. https://doi.org/10.1007/s11101-017-9534-0.

Nascimento, L.B.D.S., Leal-Costa, M.V., Menezes, E.A., Lopes, V.R., Muzitano, M.F., Costa, S.S., Tavares, E.S., 2015. Ultraviolet-B radiation effects on phenolic profile and flavonoid content of Kalanchoe pinnata. J. Photochem. Photobiol. B Biol. 148, 73-81. https://doi.org/10.1016/j.jphotobiol.2015.03.011.
Nielsen, A.H., Olsen, C.E., Møller, B.L., 2005. Flavonoids in flowers of 16 Kalanchoë blossfeldiana varieties. Phytochemistry 66, 2829-2835. https://doi.org/10.1016/j. phytochem.2005.09.041.

Okwu, D.E., Nnamdi, F.U., 2011. Two novel flavonoids from Bryophyllum pinnatum and their antimicrobial activity. J. Chem. Pharm. Res. 3, 1-10.

Ong, K.C., Khoo, H.E., 1997. Biological effects of myricetin. Gen. Pharmacol. 29, 121-126. https://doi.org/10.1016/S0306-3623(96)00421-1.

Oroian, M., Escriche, I., 2015. Antioxidants: Characterization, natural sources, extraction and analysis. Food Res. Int. 74, 10-36. https://doi.org/10.1016/J. FOODRES.2015.04.018.

Parejo, I., Jauregui, O., Sánchez-Rabaneda, F., Viladomat, F., Bastida, J., Codina, C., 2004. Separation and characterization of phenolic compounds in fennel (Foeniculum vulgare) using liquid chromatography-negative electrospray ionization tandem mass spectrometry. J. Agric. Food Chem. 52, 3679-3687. https://doi.org/10.1021/ jf030813h.

Pereira, O.R., Peres, A.M., Silva, A.M.S., Domingues, M.R.M., Cardoso, S.M., 2013. Simultaneous characterization and quantification of phenolic compounds in Thymus $\mathrm{x}$ citriodorus using a validated HPLC-UV and ESI-MS combined method. Food Res. Int. 54, 1773-1780. https://doi.org/10.1016/j.foodres.2013.09.016.

Quazi Majaz, A., Tatiya, A.U., Khurshid, M., Nazim, S., Siraj, S., 2011. The miracle plant (Kalanchoe pinnata): a phytochemical and pharmacological review. Int. J. Res. Ayurveda Pharm. 2, 1478-1482.

Richwagen, N., Lyles, J.T., Dale, B.L.F., Quave, C.L., 2019. Antibacterial activity of Kalanchoe mortagei and $K$. fedtschenkoi against ESKAPE pathogens. Front. Pharmacol. 10, 1-13. https://doi.org/10.3389/fphar.2019.00067.

Semwal, D.K., Semwal, R.B., Combrinck, S., Viljoen, A., 2016. Myricetin: A dietary molecule with diverse biological activities. Nutrients 8, 1-31. https://doi.org/ 10.3390/nu8020090.

Sharma, A., Shahzad, B., Rehman, A., Bhardwaj, R., Landi, M., Zheng, B., 2019. Response of phenylpropanoid pathway and the role of polyphenols in plants under abiotic stress. Molecules 24, 1-22. https://doi.org/10.3390/molecules24132452.

Souilem, F., Fernandes, Â., Calhelha, R.C., Barreira, J.C.M., Barros, L., Skhiri, F., Martins, A., Ferreira, I.C.F.R., 2017. Wild mushrooms and their mycelia as sources of bioactive compounds: Antioxidant, anti-inflammatory and cytotoxic properties. Food Chem. 230, 40-48. https://doi.org/10.1016/j.foodchem.2017.03.026.

Srinivas Raghavan, B., Kondath, S., Anantanarayanan, R., Rajaram, R., 2015. Kaempferol mediated synthesis of gold nanoparticles and their cytotoxic effects on MCF-7 cancer cell line. Process Biochem. 50, 1966-1976. https://doi.org/10.1016/j. procbio.2015.08.003.

Stefanowicz-Hajduk, J., Asztemborska, M., Krauze-Baranowska, M., Godlewska, S., Gucwa, M., Moniuszko-Szajwaj, B., Stochmal, A., Ochocka, J.R., 2020a. Identification of flavonoids and bufadienolides and cytotoxic effects of Kalanchoe daigremontiana extracts on human cancer cell lines. Planta Med. 86, 239-246. https://doi.org/10.1055/a-1099-9786.

Stefanowicz-Hajduk, J., Hering, A., Gucwa, M., Hałasa, R., Soluch, A., Kowalczyk, M., Stochmal, A., Ochocka, R., 2020b. Biological activities of leaf extracts from selected Kalanchoe species and their relationship with bufadienolides content. Pharm. Biol. 58, 732-740. https://doi.org/10.1080/13880209.2020.1795208.

Stiborová, M., Poljaková, J., Martínková, E., Bořek-Dohalská, L., Eckschlager, T., Kizek, R., Frei, E., 2011. Ellipticine cytotoxicity to cancer cell lines-a comparative study. Interdiscip. Toxicol. 4, 98-105. https://doi.org/10.2478/v10102-011-0017-7.

Supratman, U., Fujita, T., Akiyama, K., Hayashi, H., 2001. Insecticidal compounds from Kalanchoe daigremontiana x tubiflora. Phytochemistry 58, 311-314. https://doi.org/ 10.1016/S0031-9422(01)00199-6.

Tahir, N.I., Shaari, K., Abas, F., Parveez, G.K.A., Ishak, Z., Ramli, U.S., 2012. Characterization of apigenin and luteolin derivatives from oil palm (Elaeis guineensis Jacq.) leaf using LC-ESI-MS/MS. J. Agric. Food Chem. 60, 11201-11210.

Tanko, Y., 2012. Antinociceptive and anti-inflammatory activities of ethanol extract of Bryophyllum pinnatum laboratory animals. IOSR J. Dent. Med. Sci. 3, 46-49. https:// doi.org/10.9790/0853-0314649.

Tatsimo, S.J.N., Tamokou, J.D.D., Havyarimana, L., Csupor, D., Forgo, P., Hohmann, J., Kuiate, J.R., Tane, P., 2012. Antimicrobial and antioxidant activity of kaempferol rhamnoside derivatives from Bryophyllum pinnatum. BMC Res. Notes 5, 1-6. https:// doi.org/10.1186/1756-0500-5-158.

Tsao, R., Deng, Z., 2004. Separation procedures for naturally occurring antioxidant phytochemicals. J. Chromatogr. B 812, 85-99. https://doi.org/10.1016/J. JCHROMB.2004.09.028.

Vallverdú-Queralt, A., Jáuregui, O., Di Lecce, G., Andrés-Lacueva, C., LamuelaRaventós, R.M., 2011. Screening of the polyphenol content of tomato-based products through accurate-mass spectrometry (HPLC-ESI-QTOF). Food Chem. 129, 877-883. https://doi.org/10.1016/j.foodchem.2011.05.038.

Xu, H.X., Lee, S.F., 2001. Activity of plant flavonoids against antibiotic-resistant bacteria. Phytother. Res. 15, 39-43. https://doi.org/10.1002/1099-1573(200102)15:1<39:: aid-ptr684>3.0.c0;2-r.

Yadav, N.P., Dixit, V.K., 2003. Hepatoprotective activity of leaves of Kalanchoe pinnata Pers. J. Ethnopharmacol. 86, 197-202. https://doi.org/10.1016/S0378-8741(03) 00074-6.

Ziani, B.E.C., Barros, L., Boumehira, A.Z., Bachari, K., Heleno, S.A., Alves, M.J., Ferreira, I.C.F.R., 2018. Profiling polyphenol composition by HPLC-DAD-ESI/MSn and the antibacterial activity of infusion preparations obtained from four medicinal plants. Food Funct. 9, 149-159. https://doi.org/10.1039/c7fo01315a. 